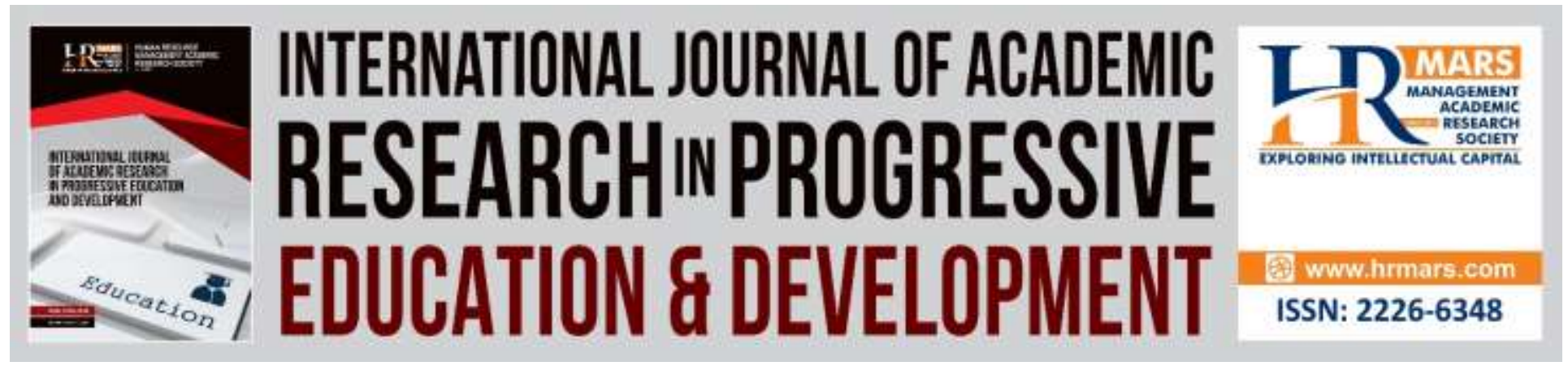

\title{
The Development of the Curriculum Fidelity Scale
}

\author{
Gurbuz Ocak, Burak Olur
}

To Link this Article: http://dx.doi.org/10.6007/IJARPED/v8-i4/6480

DOI: $10.6007 /$ IJARPED/v8-i4/6480

Received: 01 October 2019, Revised: 15 October 2019, Accepted: 30 October 2019

Published Online: 18 November, 2019

In-Text Citation: (Ocak \& Olur, 2019)

To Cite this Article: Ocak, G., \& Olur, B. (2019). The Development of the Curriculum Fidelity Scale. International Journal of Academic Research in Progressive Education and Development, 8(4), 186-200.

Copyright: (c) 2019 The Author(s)

Published by Human Resource Management Academic Research Society (www.hrmars.com)

This article is published under the Creative Commons Attribution (CC BY 4.0) license. Anyone may reproduce, distribute, translate and create derivative works of this article (for both commercial and non-commercial purposes), subject to full attribution to the original publication and authors. The full terms of this license may be seen

at: http://creativecommons.org/licences/by/4.0/legalcode

\section{Vol. 8(4) 2019, Pg. 186- 200}

http://hrmars.com/index.php/pages/detail/IJARPED

JOURNAL HOMEPAGE

Full Terms \& Conditions of access and use can be found at http://hrmars.com/index.php/pages/detail/publication-ethics 


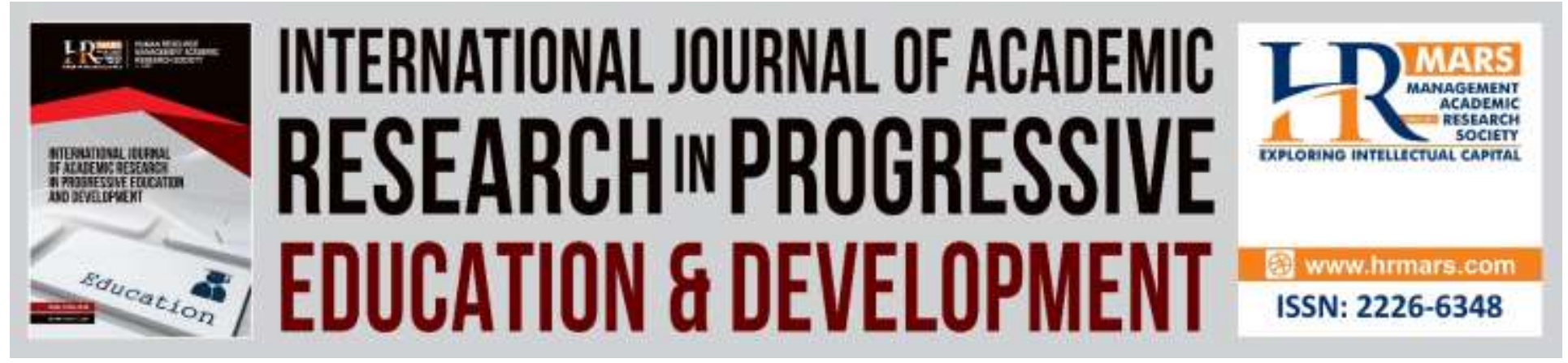

\title{
The Development of the Curriculum Fidelity Scale ${ }^{1}$
}

\author{
Gurbuz Ocak \\ Faculty of Education, Afyon Kocatepe University, Afyonkarahisar, Turkey \\ Email: gurbuzocak@gmail.com \\ Burak Olur \\ Social Sciences Institution, Afyon Kocatepe University, Afyonkarahisar, Turkey \\ Email: burakolur@gmail.com
}

\begin{abstract}
The purpose of this study is to develop a five-point likert scale called 'Curriculum Fidelity'. For this purpose, a draft scale consisting of 65 items have been represented to the expert opinion firstly and it has been decided that 15 items should be excluded. The remaining 50 items have been given to 249 teachers and the maximum likelihood has been used in the factor analysis of the scale in order to examine the structural validity. The remaining 28 items have been grouped into 3 factors. The explained variance is 62,753 of the total variance. The Cronbach's Alpha value is 0.94. Furthermore, item-total, item-remaining and item discrimination have been found significant. After exploratory factor analysis, it has been found that goodness of fit indexes are acceptable according to the results of confirmatory factor analysis (RMSEA= .075; CFI= .90; RMR= $.08 ; \mathrm{GFI}=.79 ; \mathrm{AGFI}=.76 ; \mathrm{NNFI}=.89$ ).
\end{abstract}

Keywords: Curriculum, Fidelity, Teachers

\section{Introduction}

Since the curricuulum is comprehensive and multidimensional, there are different definitions in educational resources about it. Differences in the definition of the curriculum are based on the understanding of the scientists; as they consider different dimensions of educational practices or they emphasize different dimensions of an approach. The curriculum is defined as a plan that shows all the activities that are carried out in order to create a behavioural change in the individual and all activities which are to carry out the aims of the national educational in an education institution for children, youth and adults (Erden, 1998). In addition to this definitions of the curriculum, Posner (1985) emphasizes the existence of several different programs such as the official, hidden and neglected program (Flinders, Noddings, Thornton, 1986). While the

\footnotetext{
1 This study is a part of the project supported by Afyon Kocatepe University, Scientific Research Projects Coordination Unit and is the extended version of the proceeding presented at HSCI 2018, Congress in Barcelona, Spain, 16-20 July, 2018.
} 
official curriculum which is prepared and sent to the schools is supposed to be followed, the effect of many variables such as differences in teachers' practices, school infrastructures and students differences causes the differecences in the implementation of the curriculum and that differences in the implementation of the official curriculum lead to the operational and the neglected curriculum.

It is the gospel truth that the extent to which teachers are adhere to the curriculum is one of the main reason of the emergence of the different curriculum. Therefore, it became important to examine the concept of curriculum fidelity in the United States (Dikbayır and Bumen, 2016). Curriculum fidelity is defined as the extent to which the implementers are faithful to aims of the curriculum developer (Dane ve Schneider, 1998; Domitrovich ve Greenberg, 2000), and to the extent to which the curriculum is implemented compared the original curriculum design (Mihalic, 2004).

When the literature has been reviewed, it has been concluded that the extend to which the implementers are loyal to the original curriculum is called as curriculum fidelity Mihalic, 2004; Lynch ve O'Donnell, 2005; Carroll, Patterson, Wood, Booth, Rick ve Balain, 2007; Davis, 2014) and it has also been found that this term is generally named as either curriculum fidelity (Vartuli and Rohs, 2009) or implementation fidelity (Munter ve Garrison, 2010; Durkin, Pollack, Star ve RittleJohnson, 2012; Woolley, Rose, Mercado ve Orthner, 2013).

Curriculum fidelity is defined and measured with five different dimensions (Dusenbury, Branningan, Falco, Hansen, 2003, O'Donnell, 2008) such as adherence, dose/duration, quality of delivery, participant responsiveness, and program differentiation. While it is notes that each of these dimensions are to be measured (Dane and Schneider, 1998), there are other studies which note that there is no need to measure them separately (Azano, Misset, Callahan, Oh, et al., 2011). These dimensions are defined as the following:

- Adherence: To what extend the curriculum components are implemented as the official curriculum predict,

- Dose/Duration: To what extend the duration, frequency and the number of the practices are implemented as in the official cuuriculum,

- Quality of delivery: the ability of the teachers to prepare, to trust in him/herself, to communicate clearly and to answer the questions about the topic,

- Participants responsiveness: The level of participation of the students and their interest,

- Program differentation: how well the intervention is defined and different from the other ones.

The need to measure curriculum fidelity is the main reason for understanding curriculum implementation, testing theoretical assumptions, interpreting findings, and ensuring feedback (Backer, 2001, Dane and Schenider, 1998, Domitrovich and Greenberg, 2000). Thanks to the measurement of the curriculum fidelity, feedback can be provided to the curriculum evaluation studies, as well as to the formative evaluation. From this point of view, it is very important to determine the level of curriculum fidelity of the teachers. This scale development study is important because of the lack of scales developed in this field.

\section{Method}

In this section, the study sample, scale development process and data analysis are explained. 
INTERNATIONAL JOURNAL OF ACADEMIC RESEARCH IN PROGRESSIVE EDUCATION AND DEVELOPMENT

Vol. 8, No. 4, 2019, E-ISSN: 2226-6348 @ 2019 HRMARS

\section{Participants}

The study sample consists of 249 teachers who have been working in the Aegean Region of Turkey during the academic year of 2017-2018. There are different information in the literature about sample selection in scale development studies. Kline (1994) suggests that a sample of 100 individuals may be sufficient (Cited, Pearson and Mundform, 2010).

\section{Scale Development Process (Exploratory Factor Analysis)}

At the beginning of the creating the item pools, the studies on the curriculum fidelity have been examines and the four open-ended questions have been created based on the literature.

1) What do you think about whether a teacher should be loyal to the curriculum of his / her course? Please explain.

2) In what ways do you think you loyal to the curriculum you are supposed to implement? (objectives, content, learning situation, evaluation, preparation for the course, etc.). Please explain.

3) In what ways do you think you are not loyal to the curriculum you are supposed to implement? (objectives, content, learning situation, evaluation, preparation for the course, duration, etc.). Please explain.

4) What are the positive or negative factors that affect your loyalty to the curriculum you are supposed to implement? Please explain.

The questions have been asked to five teachers from different branches (2 English Language Teachers, 1 Classroom Teacher, 1 Science Teacher, 1 Technology and Design Teacher) selected randomly and to the three phd candidate in Curriculum and Teaching. Based on the answers of the open-ended questions and the literature review, 65 items have been created expressing the curriculum fidelity. The five point likert type instrument has been presented to expert in terms of scope validity and a total of six items with narrative impairment, not related to curriculum fidelity have been excluded from the scale. After the necessary correction the remaining items havebeen applied to the 14 teacher eight of which works in Afyonkarahisar, Turkey, and the others have been reached through the internet on a voluntary basis, and it has been decided that nine items have been excluded from the scale. After all the corrections, the remaning 50 items have been applied to 249 teachers working in Afyonkarahisar, Turkey.

\section{Finding of the Exploratory Factor Analysis}

The suitability of the data for factor analysis can be assessed by the KaiserMeyer-Olkin (KMO) coefficient and the Bartlett sphericity test. KMO and Bartlett test have been used to determine the suitability of the data obtained from the application of the trial scale to factor analysis and it has been concluded that the data are suitable for the factor analysis (KMO $=.941$; Barlett sphericity $=.000$ ). Maximum likelihood has been used for factorization techniques as it is an iterative process that determines the direction and magnitude of the change in coefficients starting with the random coefficient values for the predictor set and maximizing the probability of obtaining the observed frequencies (Tabachnik and Fidell, 2013: 441). Factor loading is a coefficient explainig the relation betwen items and factors. While the factor loading of the scale should be .30 and above, it is generally preferable to have a factor loading .40 or above (Tekindal, 2015:150). In this study, the minimum value has been accepted as .40 . 
Vol. 8, No. 4, 2019, E-ISSN: 2226-6348 @ 2019 HRMARS

In exploratory factor analysis, while the factors are decided, eigen-value (Buyukozturk, 2014) and scree plot are used (Cokluk, Sekercioglu and Buyukozturk, 2014). The factors have been decided according to the eigen value on this study. As a result of the exploratory factor analysis, 22 items have been excluded from the scale and a scale consisting of 28 items and 3 sub-dimensions named as (1) Curriculum Practice Fidelity, (2) Curriculum Awareness, (3) External Effects to Fidelity.

The Cronbach's Alpha value of the scale is .944 ( $\alpha=.942$ for factor $1, \alpha=.937$ for factor $2, \alpha=$ .818 for factor 3 ). If the reliability coefficient of a scale reaches .90 , it can be said that $90 \%$ of the total variance in these scale scores is true (Tekindal, 2015: 176). The items in the 5 point Likert type scale have been graded as 'Totally Agree', 'Agree', 'Neutral', 'Disagree' and 'Totally Disagree'.

The eigenvalues and explained variance percentages of the factors are given in Table 1. below.

Table 1. The Percent of explained total variance of the curriculum fidelity scale

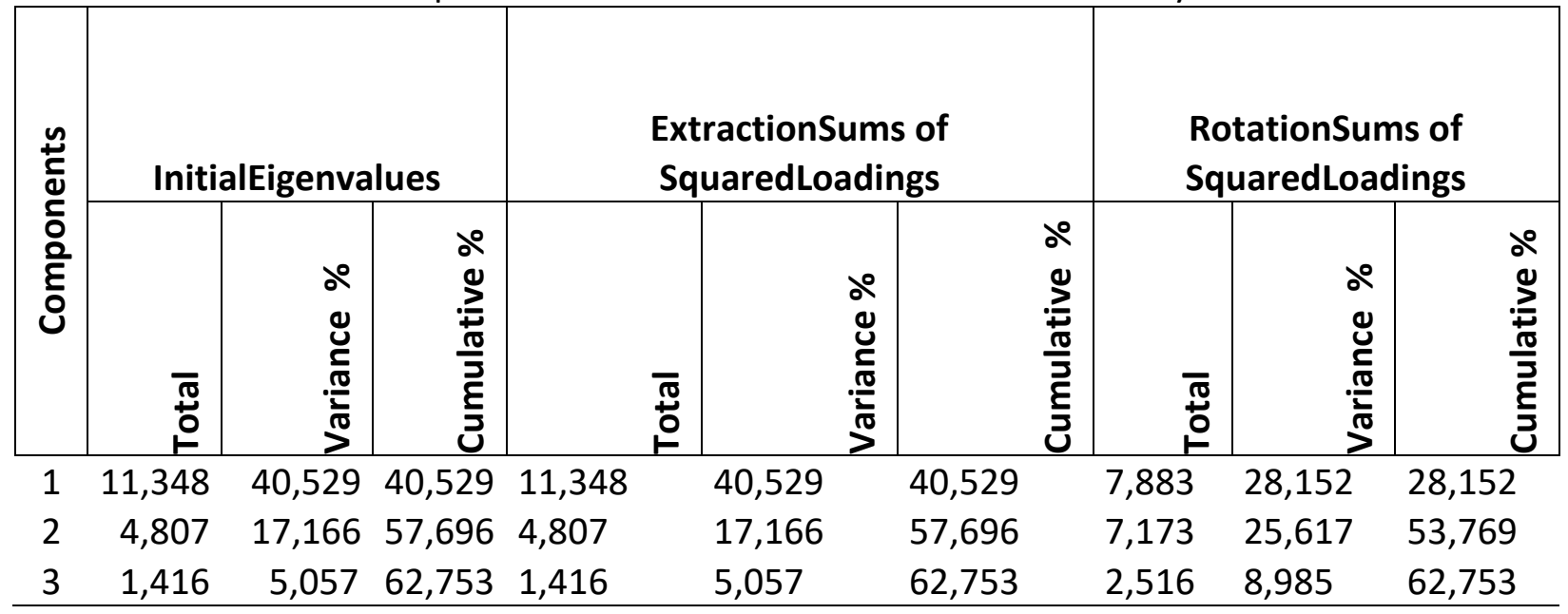

The variance explained by factor one is $40,529 \%$; it is $17,166 \%$ by factor two, 5,057 \% by factor three. The total variance explained is $62,753 \%$. The explained variance in this research can be accepted as sufficient since variance ratios between $40 \%$ and $60 \%$ are identified as ideal (Scherer, 1988). The factor loadings of the items are given below in Table 2. 
INTERNATIONAL JOURNAL OF ACADEMIC RESEARCH IN PROGRESSIVE EDUCATION AND DEVELOPMENT

Vol. 8, No. 4, 2019, E-ISSN: 2226-6348 ๑ 2019 HRMARS

Table 2. Rotated component matrix table of the curriculum fidelity scale

\begin{tabular}{|c|c|c|c|}
\hline \multirow[b]{2}{*}{ Items } & \multicolumn{3}{|c|}{ Components } \\
\hline & 1 & 2 & 3 \\
\hline Item42 & .846 & & \\
\hline Item33 & .836 & & \\
\hline Item29 & .835 & & \\
\hline Item26 & .825 & & \\
\hline Item13 & .820 & & \\
\hline Item9 & .784 & & \\
\hline Item11 & .768 & & \\
\hline Item10 & .758 & & \\
\hline Item3 & .733 & & \\
\hline Item5 & .721 & & \\
\hline Item6 & .712 & & \\
\hline Item1 & .653 & & \\
\hline Item2 & .414 & & \\
\hline Item41 & & .842 & \\
\hline Item39 & & .827 & \\
\hline Item40 & & .815 & \\
\hline Item25 & & .812 & \\
\hline Item37 & & .805 & \\
\hline Item38 & & .766 & \\
\hline Item22 & & .736 & \\
\hline Item23 & & .726 & \\
\hline Item31 & & .689 & \\
\hline Item30 & & .680 & \\
\hline Item 24 & & .517 & \\
\hline
\end{tabular}




\begin{tabular}{lll} 
Item49 & .501 & \\
Item7 & & .819 \\
Item20 & .750 \\
Item28 & .714 \\
\hline
\end{tabular}

As shown in Table 2. , it has been concluded that 13 items are under the 1st factor, 12 items are under the 2 nd factor and 3 items are under the 3 rd factor. The factor loadings for 28 items in the scale range from .404 to .846 . The factors of the scale are explained above:

\section{Factor: Curriculum Practice Fidelity}

The first factor of the scale consists of 13 items $(1,2,3,5,6,9,10,11,13,26,29,33$ and 42$)$. As a result of exploratory factor analysis, these items have been determined as 1 st, 2nd, 3rd, 4th, 5th, 6th, 7th, 8th, 9th, 10th, 11th, 12th and 13th items of the final scale. The most of the items in the first factor of the curriculum fidelity are about whether teachers apply the curriculum according to requirements, and whether they consult the curriculum or not in their practice. Based on this characteristic of the items in this factor, it has been named as the 'Curriculum Practice Fidelity'. The minimum score is 13 and the maximum score is 65 . The high scores indicate high fidelity and vice versa.

\section{Factor: Curriculum Awareness}

The second factor of the scale consists of 12 items $(22,23,24,25,30,31,37,38,39,40,41,49)$. As a result of exploratory factor analysis, these items have been determined as 14th, 15th, 16th, 17th, 18th, 19th, 20th, 21st, 22nd, 23rd, 24th, 25th items of the final scale. The most of the items in the second factor of the curriculum fidelity are about whether teachers are familiar with the curriculum. Because most of the items in the this factor require awareness, this factor of the scale has been named as Curriculum Awareness. The minimum score is 12 and the maximum score is 60. The high scores indicate high awareness and vice versa.

\section{Factor: External Effects to Fidelity}

The third factor of the scale consists of 3 items $(7,20,28)$. As a result of exploratory factor analysis, these items have been determined as 26 th, 27 th, 28 th items of the final scale. All the items under the third factor of the scale are about the external effects so this factor has been named as External Effects to Fidelity. All of the items in the factor are recoded into reverse value. The minimum score is 3 and the maximum score is 15 . The high point indicate that external factors donot have an effect on currculum fidelity and vice versa.

\section{Interpretation of the Scale}

The highest score which can be taken from the scale is 140 and the lowest is 28 . The high score from the scale indicate high curriculum fidelity and the low score indicate low curriculum fidelity. The results of the item analysis of the scale have been given in Table 
INTERNATIONAL JOURNAL OF ACADEMIC RESEARCH IN PROGRESSIVE EDUCATION AND DEVELOPMENT

Vol. 8, No. 4, 2019, E-ISSN: 2226-6348 @ 2019 HRMARS

Table 3. : Item analysis of the curriculum fidelity scale

\begin{tabular}{|c|c|c|c|c|}
\hline Item & 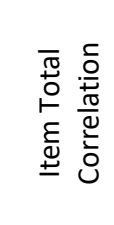 & 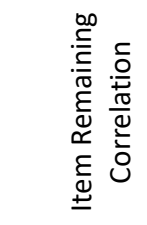 & $\mathrm{t}$ & $p$ \\
\hline Item 1 & .471 & .430 & 7,691 & .000 \\
\hline Item 2 & .654 & .622 & 13,026 & .000 \\
\hline Item 3 & .613 & .581 & 10,729 & .000 \\
\hline Item 4 & .569 & .534 & 10,509 & .000 \\
\hline Item 5 & .590 & .558 & 9,065 & .000 \\
\hline Item 6 & .621 & .589 & 11,183 & .000 \\
\hline Item 7 & .606 & .574 & 11,256 & .000 \\
\hline Item 8 & .627 & .594 & 11,666 & .000 \\
\hline Item 9 & .644 & .615 & 11,397 & .000 \\
\hline Item 10 & .572 & .538 & 10,56 & .000 \\
\hline Item 11 & .656 & .628 & 12,273 & .000 \\
\hline Item 12 & .666 & .637 & 13,026 & .000 \\
\hline Item 13 & .628 & .597 & 11,380 & .000 \\
\hline Item 14 & .639 & .600 & 12,686 & .000 \\
\hline Item 15 & .613 & .569 & 12,257 & .000 \\
\hline Item 16 & .634 & .598 & 12,288 & .000 \\
\hline Item 17 & .692 & .656 & 14,900 & .000 \\
\hline Item 18 & .670 & .631 & 14,781 & .000 \\
\hline Item 19 & .607 & .564 & 11,214 & .000 \\
\hline Item 20 & .714 & .679 & 16,507 & .000 \\
\hline Item 21 & .719 & .686 & 18,103 & .000 \\
\hline Item 22 & .705 & .671 & 17,568 & .000 \\
\hline Item 23 & .656 & .617 & 13,329 & .000 \\
\hline Item 24 & .696 & .662 & 15,809 & .000 \\
\hline Item 25 & .696 & .666 & 12,529 & .000 \\
\hline Item 26 & .559 & .516 & 8,588 & .000 \\
\hline Item 27 & .658 & .622 & 12,759 & .000 \\
\hline Item 28 & .534 & .487 & 9,362 & .000 \\
\hline
\end{tabular}

As a result of the correlation analysis for item-total and item remaining, it has been concluded that there is a meaningful correlation between all the items and the scale. The result of the independent t-test for the high group (27\%) and low group (27\%) has shown that each item has a meaningful and significant discrimination feature. 
INTERNATIONAL JOURNAL OF ACADEMIC RESEARCH IN PROGRESSIVE EDUCATION AND DEVELOPMENT

Vol. 8, No. 4, 2019, E-ISSN: 2226-6348 @ 2019 HRMARS

\section{Confirmatory Factor Analysis}

Confirmatory factor analysis is an analysis in which a previously defined structure has been tested as a model. With this analysis, it is tried to prove that the observed variables are related with latent variables and the the latent variables are interrelated with each others (Cokluk, Sekercioglu, Buyukozturk, 2014:275). A model has been created via naming the Curriculum Fidelity Scale. It has been decided that the factors of the scale are about practice fidelity, curriculum awareness and external effects, respectively and this model has been test by confirmatory factor analysis. The items about curriculum fidelity are a1-a13; the items about the curriculum awareness are a14-a25 and the items about the external effects are a26-a28. The subscale and the scale reliability coefficients of this model tested with DFA have been calculated. The path diagram of the 'Curriculum Fidelity Scale' has been given in Figure 1.

Figure 1. The significance level of the latent variables' explanation rate on the observed variables

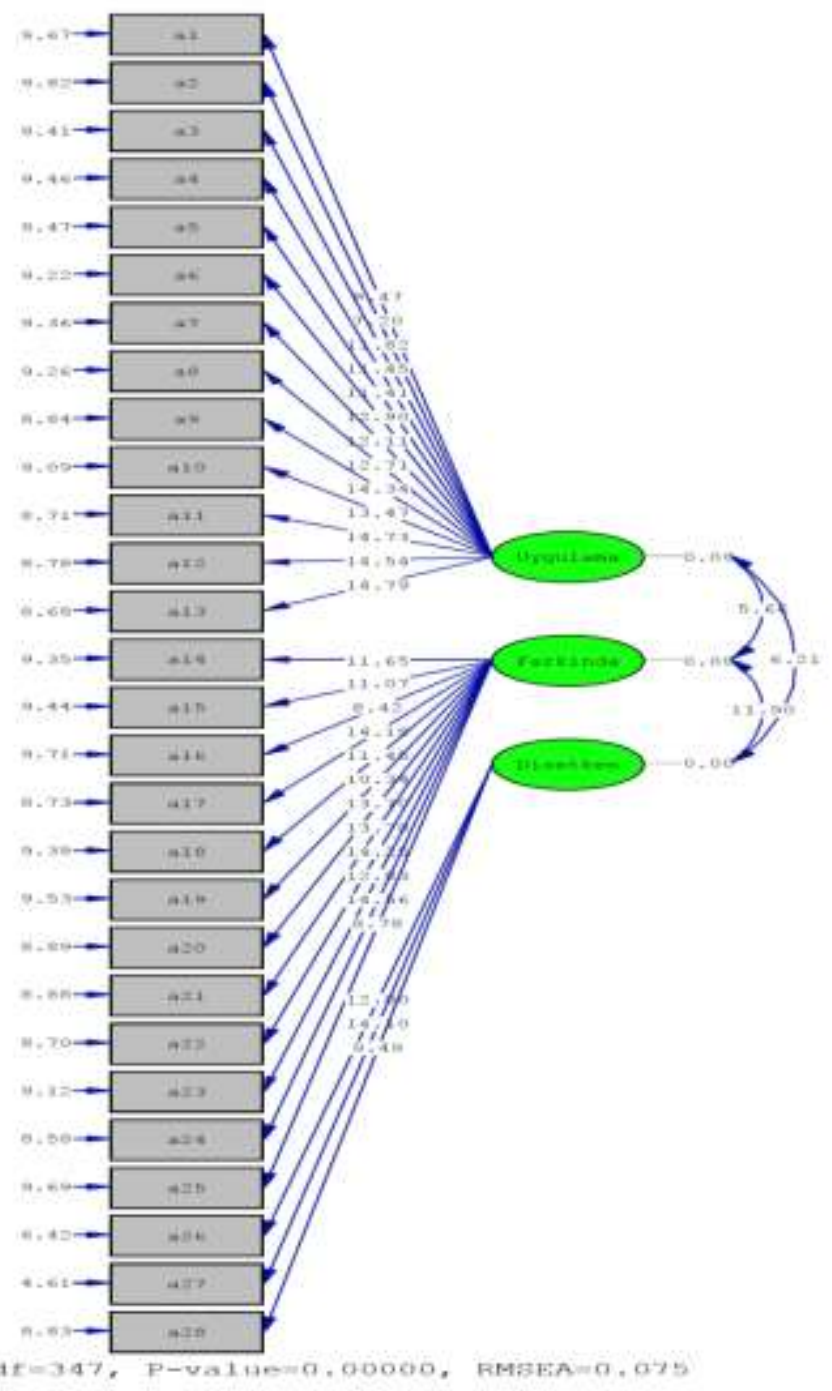


Vol. 8, No. 4, 2019, E-ISSN: 2226-6348 @ 2019 HRMARS

T values of the latent variables for explaining the observed variables are seen on the arrows. It is indicated that if $t$ values exceed 1.96; they are accepted significant at he level of .05 and if they exceed 2.56, they are accepted significant at level of .01 (Cokluk, Sekercioglu ve Buyukozturk, 2014). As seen in the figure 1 , all the parameter estimations are significant at the level of .01.

Sekil 2. : The error variance of the path diagram of curriculum fidelity scale

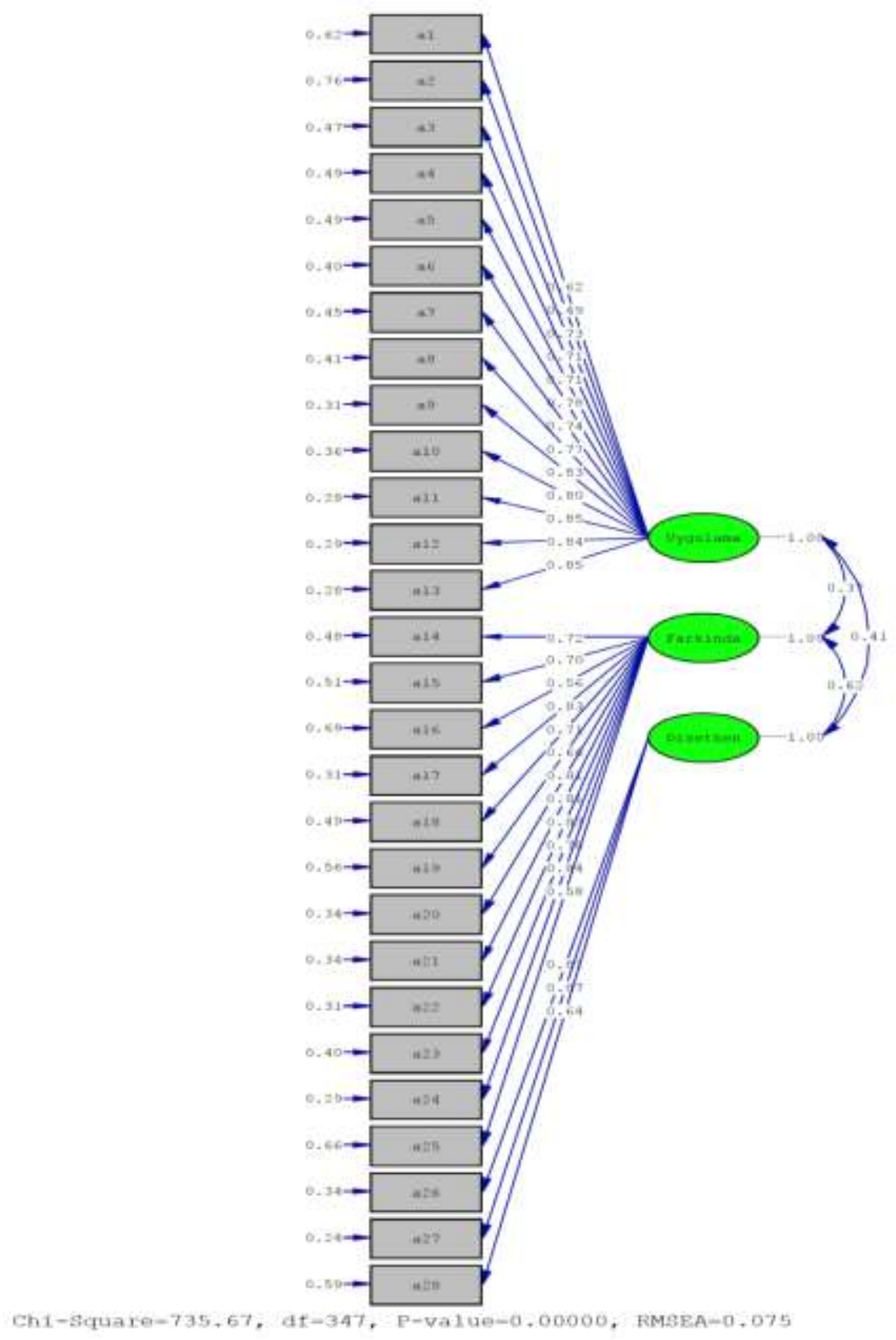

The error variance of the curriculum fidelity scale has been given in Figure 2 . When the items are evaluated, it has been concluded that item a2 and a16 have the highest error variance. It has 
INTERNATIONAL JOURNAL OF ACADEMIC RESEARCH IN PROGRESSIVE EDUCATION AND DEVELOPMENT

Vol. 8, No. 4, 2019, E-ISSN: 2226-6348 @ 2019 HRMARS

been decided that all the items can be included in the model as all the $t$ values of the items are significance.

Figure 3. Results of confirmatory factor analysis

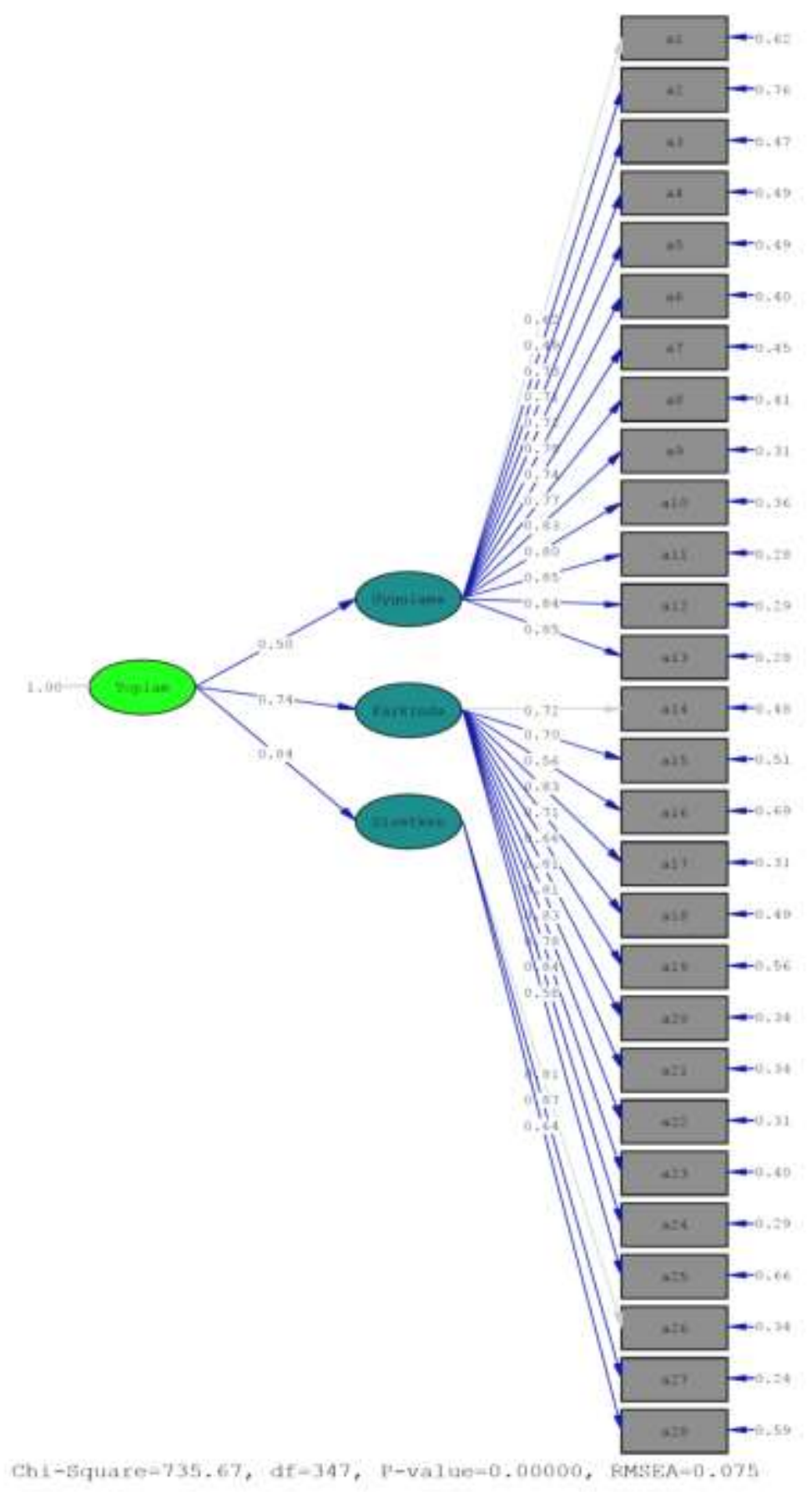


INTERNATIONAL JOURNAL OF ACADEMIC RESEARCH IN PROGRESSIVE EDUCATION AND DEVELOPMENT

Vol. 8, No. 4, 2019, E-ISSN: 2226-6348 @ 2019 HRMARS

Table 4. CFA goodness of fit results of curriculum fidelity scale

\begin{tabular}{cccc}
\hline Fitness Indexes & $\begin{array}{c}\text { Proposed Fitness } \\
\text { Value }\end{array}$ & Criteria & Acceptable Criteria \\
\hline$\chi 2 / \mathrm{df}$ & 2,12 & $0 \leq \chi 2 / \mathrm{df} \leq 2$ & $2<\chi 2 / \mathrm{df} \leq 3$ \\
\hline RMSEA & .075 & $0 \leq \mathrm{RMSEA} \leq .05$ & $.05<\mathrm{RMSEA} \leq .08$ \\
\hline $\begin{array}{c}\text { Comperative Fit } \\
\text { Indeks (CFI) }\end{array}$ & .90 & $.95 \leq \mathrm{CFI} \leq 1.00$ & $.90 \leq \mathrm{CFI}<.95$ \\
\hline $\begin{array}{c}\text { Standartized RMR } \\
\begin{array}{c}\text { Goodness of Fit } \\
\text { Indeks (GFI) }\end{array}\end{array}$ & .08 & $0 \leq \mathrm{SRMR} \leq .05$ & $.05<\mathrm{SRMR} \leq .10$ \\
\hline $\begin{array}{c}\text { Adjusted } \\
\text { Goodness of Fit } \\
\text { Indeks (AGFI) }\end{array}$ & .76 & $.95 \leq \mathrm{GFI} \leq 1.00$ & $.90 \leq \mathrm{GFI}<.95$ \\
\hline NNFI & .89 & $.95 \leq \mathrm{NGFI} \leq 1.00$ & $.85 \leq \mathrm{AGFI}<.90$ \\
\hline
\end{tabular}

It is stated that $\chi 2$ /df value is as low as 2.0 (Tabachnik and Fidell, 2013), RMSEA value is .08 (Browne and Sugawara, 1996), GFI value is .95 (Miles and Shevlin, 1998) shows good fitness, and Miles and Shevlin (1998) indicate that if GFI value is .95, it shows a good fitness. However, it is also indicated that GFI value can chage depend on the sample size and it should be ignored (Sharma, Mukherjee, Kumar ve Dillon, 2005). It is mentioned that if CFI gets closer to 1 , it shows good fitness; and NNFI can be accepted as low as .80 (Hooper, Coughlan ve Mullen, 2008). When the fitness indexes of the curriculum fidelity scale model have been examined, it has been concluded that the values of the model are generally at the acceptable level $(\chi 2 / d f=2,12$; $\mathrm{RMSEA}=.075 ; \mathrm{CFI} .90 ; \mathrm{RMR}=.08$ ve $\mathrm{GFI}=.79)$. These values confirm the factor structure.

\section{Conclusion and Discussion}

In this study, a scale has been developed to measure the curriculum fidelity level of the teachers. For this reason, a 5-point Likert-type draft scale consisting of 65 items has been prepared based on the literature, expert opinion and answers to the open-ended questions directed to teachers. This draft scale has been first presented to the expert opinion and 6 items have been excluded from the draft in line with the feedback from the experts. Furthermore, 9 more items have been also excluded from the draft scale after the pilot application to understand whether there are any items which cannot be fully understod or not servet he purpose of the scale. Structural validity has been tested with the remaning 50 items.

First of all, exploratory factor analysis has been carried out. As a result of the analysis, it has been concluded that KMO value $(.941)$ and the Barlett test result $(p<.05)$ have shown that the data are suitable for the factor analysis. Factor loading has been decided as .40 and the items which have a value under .40 and take place under more than one factor have been decieded to exclude from the scale. 22 items that have not met the criteria have been excluded from the scale and it has been concluded that the scale consists of 3 different factors and explains $62.75 \%$ of the total variance. 
The first factor of the scale (Curriculum Implementation Fidelity) explains the $28,152 \%$ of the total variance; and the second factor (Curriculum Awareness) explains the 25,617\% of the total variance and the last factor of the scale (External Effects to Fidelity) explains the 8,985 of the total variance. Item analyses (item remainig correlation, item total correlation and item discrimination) have been also conducted and it has been concluded that all the items have meaningful correlation and the the item discrimination is also statistically significant. The Cronbach's Alpha of the scale has been calculated as .944 .

Confirmatory factor analysis has been also employed after the exploratory factor analysis. As a result of this analysis, it has been concluded that the fit indexes of the scale are $\chi 2 / d f=2,12$; RMSEA=.075; CFI .90; RMR = .08 ve GFI=.79. In spite of not indicating a perfect fit, these values are within acceptable limits and close to acceptable limits.

It is stated that the curriculum fidelity is composed of five dimensions and these dimensions measure the fidelity together (Dane and Schneider, 1998). Considering the 'Curriculum Implementation Fidelity' and 'Curriculum Awareness' factors of the developed scale, both of the factors reflect the features of these dimensions of the curriculum fidelity. In the first dimension of the scale, the item 9 stating that 'I allocate the stated time in the curriculum for each objective.' is in accordance with dose/duration dimension of the curriculum fidelity. Moreover, in the second factor of the scale, the item 22 ' I am aware of the philosophical, psychological, social and individual foundations on which the curriculum is based' is related with the program differentation dimension which means how well the intervention is defined and different from the other ones (Pence, Justice ve Wiggins, 2008). Besides, the item 15 'I can answer the questions about the objectives within the curriculum clearly and sufficiently' and the item 19 'I am aware of the task the teacher has during the curriculum implementation.' are two examples for the quality delivery, the ability of the teachers to prepare, to trust in him/herself, to communicate clearly and to answer the questions about the topic, and for the participants responsiveness, the level of participation of the students and their interest (Dusenbury, Branningan, Falco, Hansen, 2003; O'Donnell, 2008; Pence, Justice ve Wiggins, 2008).

In our country, while the factors that may have an impact on curriculum fidelity are considered, the factors such as socio-cultural structure, centralization and exams that determine student's future are also mentioned (Bumen, Cakar and Yıldız, 2014). In our country, the factor that is thought to have the biggest effect on the curriculum fidelity is the central examinations. Accordingly, the items under the third factor of the scale 'The External Effects to Fidelity, aim to reveal the extent to which the exams affects the curriculum fidelity.

As a result of the analyses, it can be accepted that Curriculum Fidelity Scale is a valid and reliable measurement tool.

As it is a progressive procedure to develop and evaluate a curriculum, it is vital to give feedbacks to the system systematically. This scale is useful for both to reveal the fact that to what extend the teachers adopt the implemented currciulum, and what hinders their fidelity to it as well as contributing to all partners that are in the curriculum development and evaluation process. As there are few scale on the curriculum fidelity, this scale will play an important role in providing quantitative data to the researchers and legislatures in the field of education especially in curriculum and instruction. 
INTERNATIONAL JOURNAL OF ACADEMIC RESEARCH IN PROGRESSIVE EDUCATION AND DEVELOPMENT

Vol. 8, No. 4, 2019, E-ISSN: 2226-6348 ㄷ 2019 HRMARS

\section{References}

Aykac, N. \& Ulubey, O. (2012). Ogretmen adaylarının ilkogretim programının uygulanma duzeyine iliskin gorusleri. Ankara Universitesi Egitim Bilimleri Fakultesi Dergisi, 45(1):63-82.

Azano, A., Missett, T. C., Callahan, C. M., Oh, S., Brunner, M., Foster, L. H. \& Moon, T. R. (2011). Exploring the relationship between fidelity of implementation and academic achievement in a third-grade gifted curriculum: A mixed-methods study. Journal of Advanced Academics, 22(5), 693-719.

Backer, T. E. (2001). Finding the balance: Program fidelity and adaptation in substance abuse prevention: A state of the art review. Rockville, MD: Center for Substance Abuse Prevention. https://www.csun.edu/sites/default/files/FindingBalance1.pdf Erisim Tarihi: 20.10.2017.

Bumen, N. T., Cakar, E. \& Yildiz, D. G. (2014). Curriculum fidelity and factors affecting fidelity in the Turkish Context. Educational Sciences: Theory and Practice, 14(1), 219-228.

Buyukozturk, S. (2014). Sosyal bilimler icin veri analizi el kitabı. Pegem Akademi: Ankara.

Carroll, C., Patterson, M., Wood, S., Booth, A., Rick, J. \& Balain, S. (2007). A conceptual framework for implementation fidelity. Implementation science, 2(1), 40.

Cokluk, O., Sekercioglu, G. \& Buyukozturk, S. (2014). Sosyal bilimler icin cok degiskenli istatistik: SPSS ve LISREL uygulamaları. Pegem Akademi.Ankara.

Dane, A. V. \& Schneider, B. H. (1998). Program integrity in primary and early secondary prevention: Are implementation effects out of control. Clinical Psychology Review, 18, 23-45.

Davis, D. (2014). Fidelity of implementation, teacher perspectives and child outcomes of a literacy intervention in a head start program: A mixed methods study. Dissertation, University of Nebraska, Lincoln.

https://digitalcommons.unl.edu/cgi/viewcontent.cgi?article=1203\&context=cehsdiss Erisim Tarihi: 21.11.2017.

Dikbayır, A. \& Bumen, N. (2016). Dokuzuncu sınıf matematik dersi Ogretim Programına Baglılıgın Incelenmesi. International Journal of Curriculum and Instructional Studies, 6(11).

Domitrovich, C. E. \& Greenberg, M. T. (2000). The study of implementation: Current findings from effective programs that prevent mental disorders in school-aged children. Journal of Educational and Psychological Consultation, 11, 193-221.

Durkin, K., Pollack, C., Star, J. R. \& Rittle-Johnson, B. (2012). Differences in Fidelity of Implementation Measures: What Videos and Surveys Reveal about Algebra Instruction. Society for Research on Educational Effectiveness. 2010 SREE Conference.

Dusenbury, L., Branningan, R., Falco, M., \& Hansen, W. B. (2003). A review of research on fidelity of implementation: Implications for drug abuse prevention in school settings. Health Education Research, 18, 237-256.

Hooper, D., Coughlan, J., \& Mullen, M. (2008). Structural equation modelling: guidelines for determining model fit. Electronic Journal of Business Research Methods, 6(1), 53-60.

Lynch, S. \& O'Donnell, C. (2005). The evolving definition, measurement, and conceptualization of fidelity of implementation in scale-up of highly rated science curriculum units in diverse middle schools. Paper presented at the symposium on "Fidelity of Implementation" at the Annual Meeting of the American Educational Research Association, Montreal, Canada. 
INTERNATIONAL JOURNAL OF ACADEMIC RESEARCH IN PROGRESSIVE EDUCATION AND DEVELOPMENT

Vol. 8, No. 4, 2019, E-ISSN: 2226-6348 @ 2019 HRMARS

https://www2.gwu.edu/ scale-up/documents/AERA_GWU_Fidelity_4.12.05.pdf. Erisim Tarihi: 22.10.2017.

MacCallum, R. C., Browne, M. W. \& Sugawara, H. M. (1996). Power analysis and determination of sample size for covariance structure modeling. Psychological Methods, 1 (2), 130-49.

Mihalic, S. (2004). The importance of implementation fidelity. Emotional \& Behavioral disorders in youth. Vol: 4, No: 4, pp. 83-105.

http://www.blueprintsprograms.com/publications/EBDY_4-4--Mihalic.pdf. Erisim: 18.10.2017.

Mihalic, S. F., Fagan, A. A. \& Argamaso, S. (2008). Implementing the LifeSkills Training drug prevention program: factors related to implementation fidelity. Implementation Science, 3(1), 5.

Miles, J. \& Shevlin, M. (2007). A time and a place for incremental fit indices. Personality and Individual Differences, 42 (5), 869-74.

Munter, C., Garrison, A., Cobb, P. \& Cordray, D. (2010). Evaluating math recovery: Measuring fidelity of implementation. Society for Research on Educational Effectiveness. https://files.eric.ed.gov/fulltext/ED514496.pdf. Erisim Tarihi: 28.10.2017.

O'Donnell, C. L. (2008). Defining, conceptualizing, and measuring fidelity of implementation and its relationship to outcomes in $\mathrm{K}-12$ curriculum intervention research. Review of Educational Research, 78(1), 33-84.

Pence, K. L., Justice, L. M. \& Wiggins, A. K. (2008). Preschool teachers' fidelity in implementing a comprehensive language-rich curriculum. Language, Speech, and Hearing Services in Schools, 39, 329-341.

Sharma, S., Mukherjee, S., Kumar, A. \& Dillon, W. R. (2005). A simulation study to investigate the use of cutoff values for assessing model fit in covariance structure models. Journal of Business Research, 58 (1), 935-43.

Tabachnick, B. G., \& Fidell, L. S. (2013). Using multivariate statistics (6th ed.). New York: Pearson. Tavsancıl, E. (2014). Tutumların olculmesi ve SPSS ile veri analizi. Nobel Yayıncılık, Ankara.

Tekbıyık, A. \& Akdeniz, A. R. (2008). Illkogretim fen ve teknoloji dersi ogretim programını kabullenmeye ve uygulamaya yonelik ogretmen gorusleri. Necatibey Egitim Fakultesi Elektronik Fen ve Matematik Egitimi Dergisi, 2(2):23-37.

Tekindal, S. (2015). Duyussal ozelliklerin olculmesi icin arac olusturma. Pegem Akademi: Ankara.

Vartuli, S. \& Rohs, J. (2009). Assurance of outcome evaluation: Curriculum fidelity. Journal of Research in Childhood Education, 23(4), 502-512.

Woolley, M. E., Rose, R. A., Mercado, M. \& Orthner, D. K. (2013). Teachers teaching differently: A qualitative study of implementation fidelity to professional development. Journal of Education and Training Studies, 1(1), 55-68. 